\begin{tabular}{|l|l|l|l|l|}
\hline ACTA CARSOLOGICA & $32 / 1$ & 8 & $101-120$ & LJUBLJANA 2003 \\
\hline
\end{tabular}

COBISS: 1.08

\title{
PALEOSEISMIC PHENOMENA IN KARST TERRAINS IN BULGARIA AND MOROCCO
}

\section{PALEOSEIZMIČNI POJAVI NA KRASU V BOLGARIJI IN V MAROKU}

DORA ANGELOVA ${ }^{1} \&$ M'HAMED ALAEDDIN BELFOUL $^{2} \&$ SOPHIA BOUZID ${ }^{2} \&$ MUSTAPHA FILAHI ${ }^{3} \&$ FARID FAIK $^{2}$

${ }^{1}$ Geological Institute, Bulgarian Academy of Sciences, Acad. G. Bonchev St., Bl. 24, 1113 SOFIA, BULGARIA, e-mail: doraangelova@hotmail.com

${ }^{2}$ Department of Geology, Faculty of Sciences, Ibnou Zohr University, AGADIR 80000, MOROCCO, e-mail: aladinbel@yahoo.fr, sbouzid@yahoo.fr

${ }^{3}$ Faculty of Sciences and Technique, BENI MELLAL 23000, MOROCCO, e-mail: filahi4@voila.fr 


\section{Dora Angelova \& M'hamed Alaeddin Belfoul \& Sophia Bouzid \& Mustapha Filahi \& Farid Faik: Paleoseismic phenomena in karst terrains in Bulgaria and Morocco}

During the recent years there has been a growing interest in recording and investigating the effects of paleoseismic events in surface and underground karst in almost all countries. Karst represents a reliable reference marker for understanding the potential seismicity in regions with instrumentally established low to moderate seismicity. The karst terrains in Bulgaria and Morocco occupy considerable areas. The disturbances in surface and underground karst had usually been provoked by catastrophic one-act events or by repeatedly activated movements by earthquakes. The catastrophic seismic events had disturbed the naturally interrelated karst ecosystems and were the reason for rejuvenation, reactivation or attenuation of karst processes. The natural surface and underground relief had been partially or entirely destroyed; a new type of relief had been formed; the geological environment had been disturbed; changes occurred in the flowrate and direction of surface and underground karst water; wetlands of the gravitation type had been formed; natural caves, local grabens, rock-falls and landslides collapsed partially or entirely and terrains were subjected to subsidence and destruction; the ecological balance in urbanized territories had been disturbed. The present work considers the different types of paleoseismic phenomena in the karst terrains in Bulgaria and Morocco. Recommendations are given for the protection of these areas.

Key words: paleoseismic phenomena, karst, Bulgaria, Morocco, seismothems, seismogravitation forms.

\section{Izvleček}

UDK: 551.44:550.34(497.2+64)

\section{Dora Angelova \& M'hamed Alaeddin Belfoul \& Sophia Bouzid \& Mustapha Filahi \& Farid Faik: Paleoseizmični pojavi na krasu v Bolgariji in v Maroku.}

V zadnjih letih narašča zanimanje za beleženje in raziskovanje učinkov paleoseizmičnih dogodkov na kraškem površju in v podzemlju. Kras je lahko zanesljiva referenčna točka za razumevanje potencialne seizmičnosti na področjih, kjer opazovalni inštrumenti kažejo nizko oziroma zmerno seizmičnost. V Bolgariji in Maroku zavzema kras velike površine. Spremembe na kraškem površju in v podzemlju navadno povzročijo katastrofalni trenutni dogodki ali pa ponavljajoča se premikanja zaradi potresov. Katastrofalni potresni dogodki so spremenili medsebojno povezane kraške ekosisteme in so bili vzrok za pomlajevanje, reaktiviranje ali prekinitev kraških procesov. Naravni površinski ali podzemeljski relief sta bila deloma ali v celoti uničena; nastal je nov tip reliefa; geološko okolje je bilo spremenjeno; nastale so spremembe v količini odtoka in v smeri površinskega in podzemeljskega odtekanja kraške vode; nastali so gravitacijski tipi močvirij; kraške jame, lokalni tektonski jarki, prihajalo je do podorov in zemeljskih plazov in ozemlje je bilo podvrženo grezanju in uničenju; spremenjeno je bilo ekološko ravnotežje urbaniziranih pokrajin. V pričujočem delu je govora o različnih paleoseizmičnih pojavih na krasu v Bolgariji in v Maroku. Na podlagi preučevanja tektonskih premikov so dana priporočila za varstvo teh ozemelj.

Ključne besede: paleoseizmični pojavi, kras, seizmoteme, seizmogravitacijske oblike, Bolgarija, Maroko. 


\section{INTRODUCTION}

The karst in Bulgaria and Morocco occupy more than one third of their corresponding territories. The karst is a reliable marker for recording and investigating paleoseismic events in regions that have low or moderate seismicity at the present day. These investigations are necessary for the establishment of the indicative seismicity of terrains with limited area. Moreover, the disturbances in surface and underground karst provoked by catastrophic earthquakes had brought destruction to the naturally interrelated karst ecosystems and a new type of relief had been created. The geological and hydrogeological environment had been subjected to destruction too. Various forms were created: gravitation marshlands and caves; partially or entirely collapsed natural caves; local grabens, rock-falls and landslides, etc. In this way unique natural phenomena occurred, which are protected by legislation in Bulgaria and Morocco and by international conventions. They will be better protected and preserved if their nature and relationships with the other components of environment are known and understood. For this reason there is a growing interest in these phenomena all over the world. The investigations in Bulgaria and Morocco are still at their initial stage, the studies on surface karst being the dominating ones in Bulgaria.

\section{PALEOSEISMIC PHENOMENA}

\section{Morocco}

One of the important karstic systems in Morocco is situated about $65 \mathrm{~km}$ to the north of Agadir City. It spreads on the all-western part of the High-Atlas. This system holds the Wintimdouine cave, which is the most famous and the longest underground network actually known in North Africa. With nearly $19.7 \mathrm{~km}$ of galleries, the Wintimdouine cave presents a double interest due to its relatively easy access and due to the fact that it has been developed consistent with the main fracture network. The internal cave topography is well accommodated by fault work (Belfoul 1997; Belfoul et al. 2000). This provides a good opportunity of following all events and motions that might have affected the region, especially those induced by seismotectonic and neotectonic activities. In such, instability markers are extremely meaningful because seismothems and speleothems are rather well conserved and quite developed.

The High-Atlas in Morocco is the main form of relief in the whole of northern Africa with $4625 \mathrm{~m}$ at Toubkal Mountain to the south of Marrakech. It is considered to be an anorogenic chain developed during the opening of the Atlantic Ocean combined with the shortening and the current closing between the African and European plate. Taphrogenic data show that this chain occurred right on the ENE-WSW Triassic pull-apart basins using an inherited fault network. In the same way, a basaltic floor occurred in the Atlantic Ocean while the Atlas oceanic attempt aborted and evolved to an intracontinental system. The filling up of the pull-apart basins gave place to an important carbonate shelf since Jurassic time and during a great part of the Cretaceous period.

The Atlasic submeridian shortening was responsible for the cover decollements down sliding over a clayey Triassic to the opposite borders of the chain. In the same way, reverse faults were developed: strike slips and wide sub-equatorial folds in the shape of flat synclines and narrow anticlines, without any cleavage. 
The Atlasic system is limited at its southern border by an important accident called "Accident Sud-Atlasique" or Tizi N'Test Fault, which is still active, and expresses a big flexure that amortizes relief dislevelment to the coastal Souss plain (Fig. 1). Now the carbonate shelf is up on high

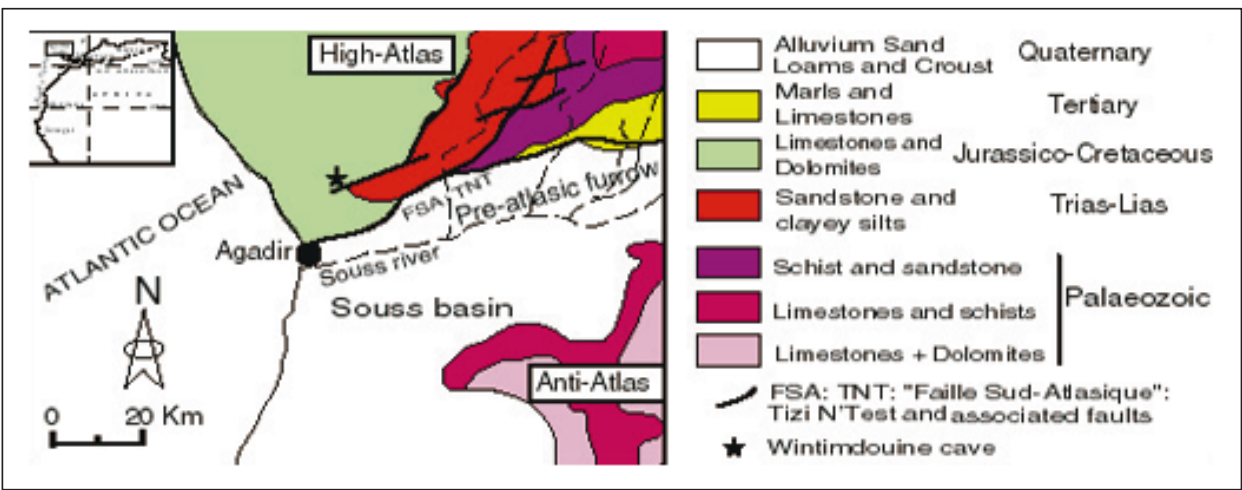

Fig. 1: Simplified geological map of the southwestern part of the High-Atlas chain.

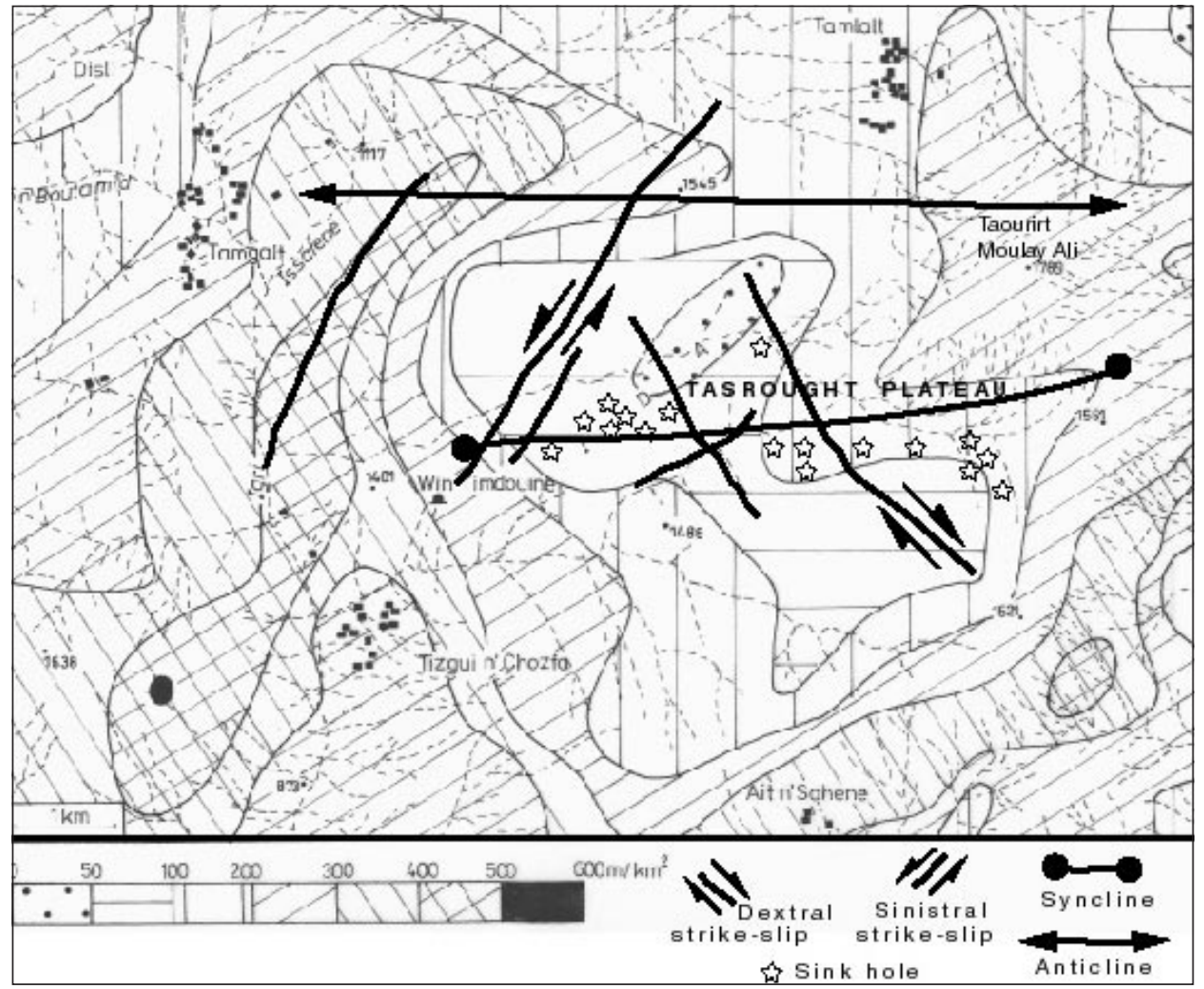

Fig. 2: Morphometric map of the karstic domain of Wintimdouine with some structural data. 
topographic levels and develops karstic well features because of the mountainous weather along the Atlantic coast. Agadir City is built on this flexure network close up to the High-Atlas karstic system, still affected by neotectonic events. This allows the approach to its paleoseismic behaviour by considering markers recorded at outcrops and cartographic scales. The investigated area concerns Jurassic-Cretaceous outcrops of the carbonate shelf.

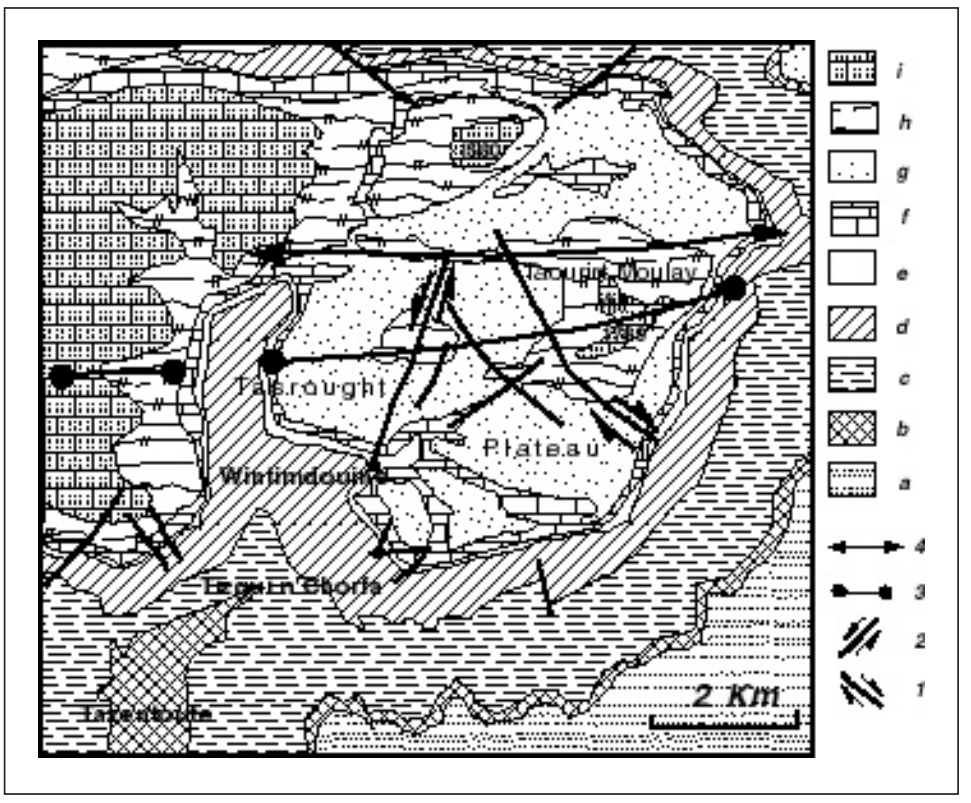

Fig. 3: Geological map of the Wintimdouine karstic domain.

1-2 - Respectively dextral and sinistral strike-slip; 3 - Syncline; 4 - Anticline; a,b,c,d,e,f,g,h,i-see Fig. 4.
The Atlasic tectonic style is of brittle-ductile tendency. Some of its major features are described below. The brittle structures are more represented in the karstic area. Centimetric crumplings are locally overfolded with northern edge the E-W wide opened synclines. These dynamics are also deduced from the E-W high sloping reversed microfaults. A strike joint network exists towards the axial part, which is compatible with

the folding trend. In the same way, conjugated sinistral NNE-SSW and dextral NNW-SSE strikeslip faults mark the Tasrought Plateau (Fig. 2 and Fig. 3).

The karstic system shows also stylolitic joints with diagenetic origin but mainly as a tectonic stress result that underlines the N-S shortening effort. Tectonic slits are in various directions, where NNE-SSW and NNW-SSE seem to be the majority. Disharmony folds are mainly localised into the crumbly levels that allow the gravitational gliding process. All these structures point of a submeridian shortening tensor with a weak plunge according to the major stress controlling the current closeness of the African and Eurasian continents.

Except for the Triassic formation, which is of argillaceous and basaltic nature (Fig. 4), limestone varieties represent the main Mesozoic and Cenozoic High-Atlas lithology. The outcrops show a composition dominated by calcareous, marl and dolomite species. Since the fold distortion in this area is quite weak, the geological structures often present a pan shape, especially at the wide synclines that characterize in this context the high relief. These particularities confer karstic behaviour to a large part of this device. 

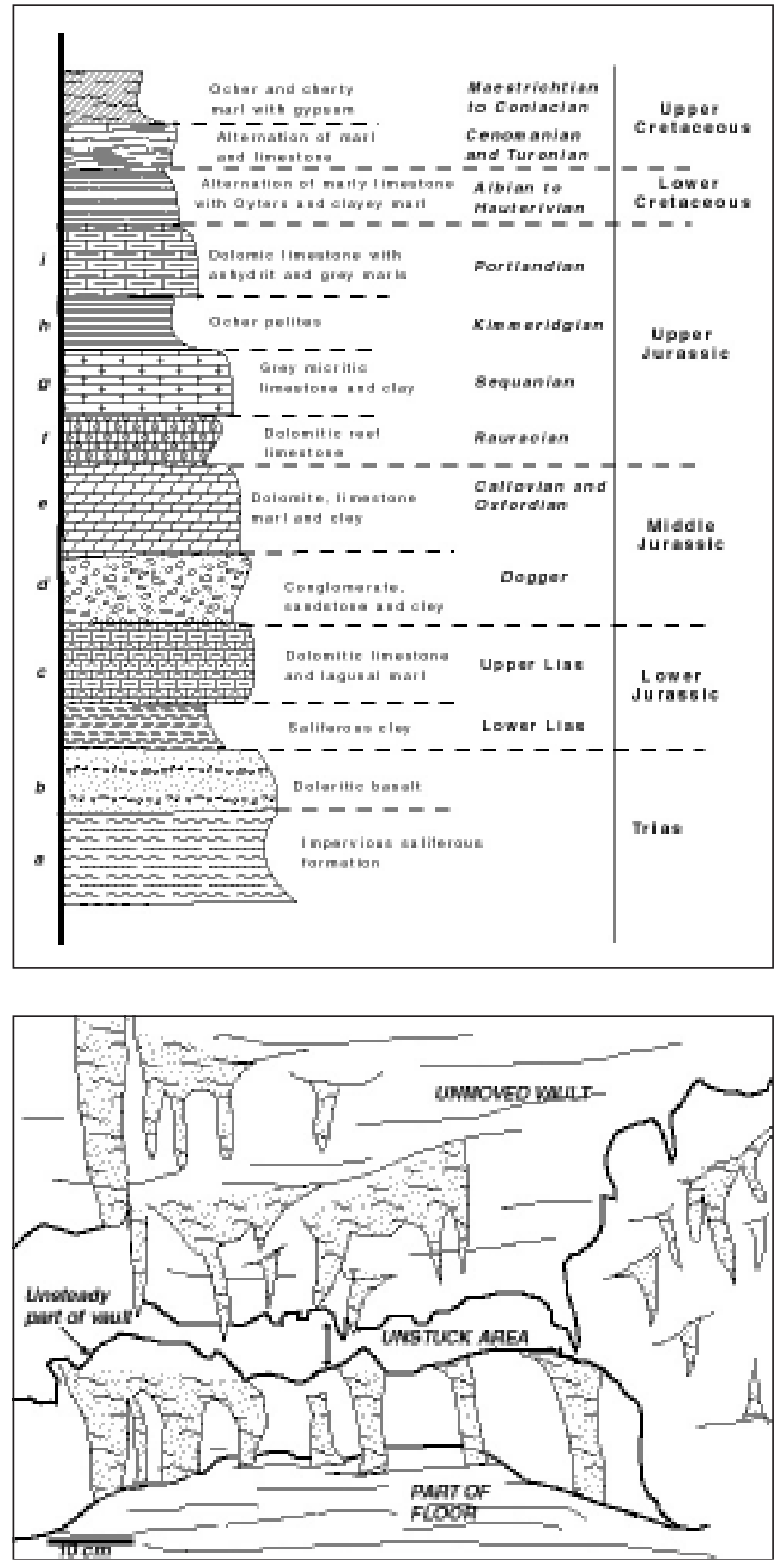

Fig. 4: Simplified stratigraphic column of the Mesozoic deposits in the western High-Atlas (From Adams et al.; 1980 modified).

The size and abundance of speleothems that have grown at a distance of about $100 \mathrm{~m}$ from the entrance of the Wintimdouine cave are very impressive. Some disturbances in this growth are very interesting (Bouzid et al. 2001) with respect to the reasons that have caused them. The main structures encountered are described below and preliminary attempts for their explanation are made before the final results of their dating have been obtained. Later the age of the events can be determined more precisely.

Figure 5 shows an unstuck roof area made of stalactites. The spacing is localised, especially where the speleothems are fixed to the floor and display an important vertical threw.

Fig. 5: Photo-drawing of a vertical movement displayed by an unstuck roof. 


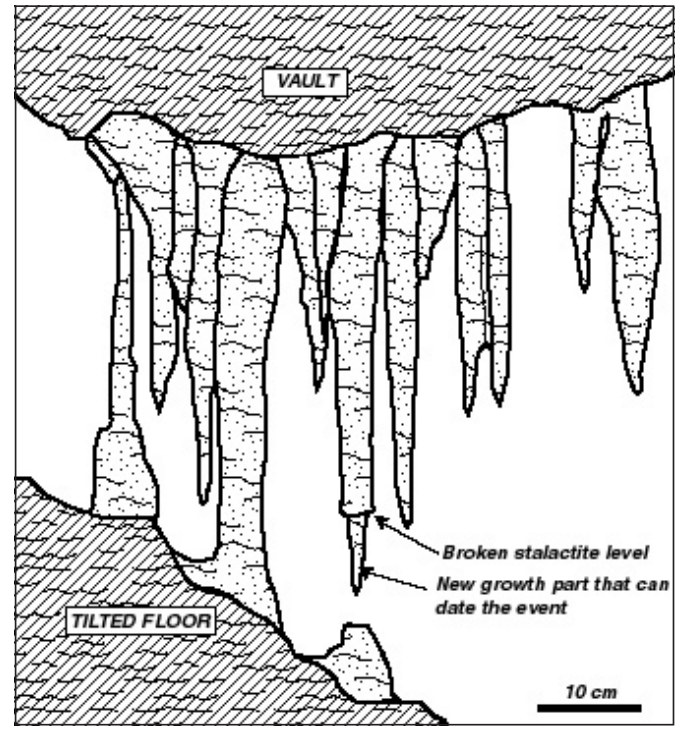

Fig. 6: Photo-drawing of a broken stalactite spike where the new growing can date the event.

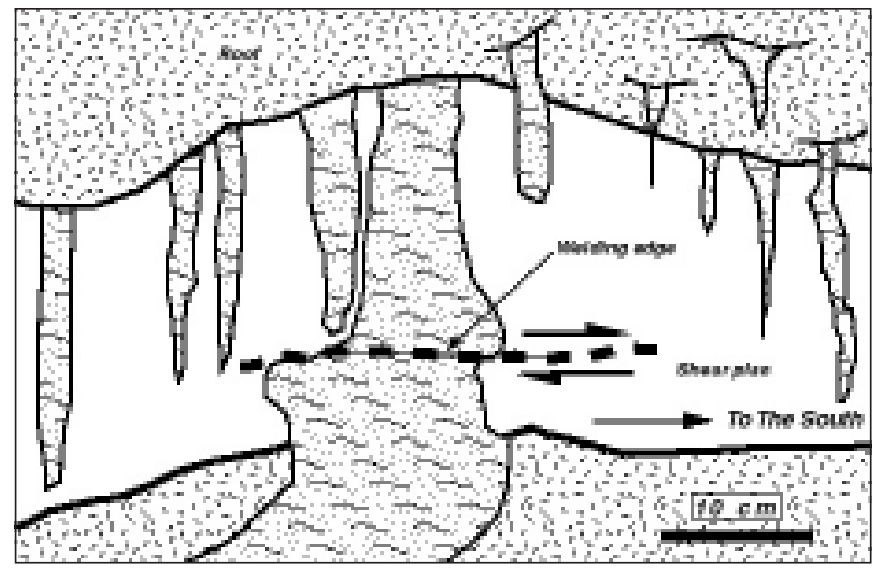

Fig. 7: Horizontal move affecting a stalagmite.

Elsewhere, broken stalactites show that the area was affected by no trifling shakes recently. This is demonstrated in Fig. 6, where a stalactite spike is a new growth from the lost part. It could be supposed that the vault and roof were glued by crystallization and then moved under a jolt. The application of U/Th geochronology technique on the stalactite new growth spike may date this event.

A horizontal throw is shown in Fig. 7, which can be measured both in time and space. An initially continuous stalagmite displays a horizontal shearing of a few centimetres. It indicates that the roof has been moved with relative translation to the south. The welded edge indicates that new crystallization has taken place and can provide material to date the shear event.

All these examples prove that the southwestern part of the High-Atlas was affected by several different movements, expressed mainly in the karstic domain of Wintimdouine.

Skakes, with vertical and horizontal shearing motions are well recorded by speleothems that must be dated later by geochronology techniques. Some distortions localized around Agadir City and some markers of the earthquake in 1960 are described below to emphasize the potential relationship between it and the different speleothem behaviour recorded in the Wintimdouine cave.

Outside the endokarstic domain, a lot of authors have already reported the existence of tectonic distortions along the southern side of the Moroccan High-Atlas (Ambroggi \& Neltner 1952; Marcais \& Choubert 1956; Duffaud 1962; Erimesco 1962; Amrhar 1989 and others), both into Plio-Quaternary and Cretaceous formations, where it is possible to follow the general uplift of all the Atlasic system. Around Agadir City, the orientation of the flexure is appreciably East-West 


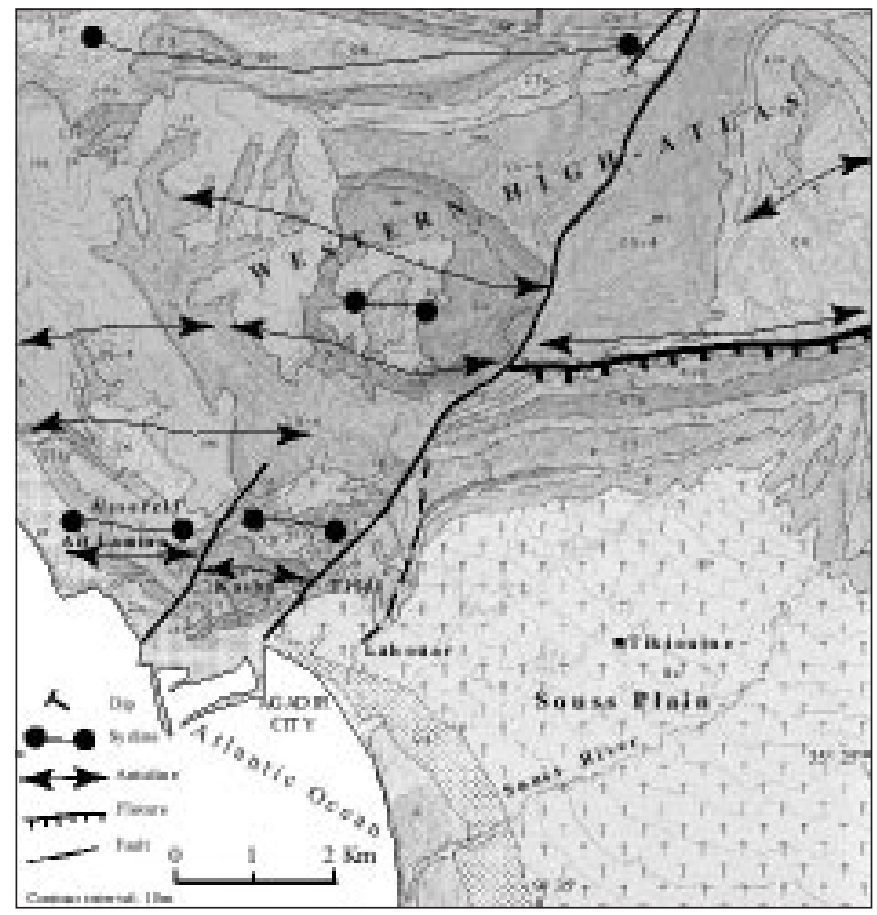

Fig. 8: Morphostructural map of Agadir area (Modified. Source: document of SCP, Morocco).

a2: Beach sand and recent alluvium; $d$ : recent dunes; Qc: Ancient Quaternary; Qm: Marine recent and medium Quaternary; Qd: Ancient encrusted dunes; Qa: Encrusted piedmont formation; $\boldsymbol{P}$ : Upper Pliocene and Villafranchian (crust, sandstone, Calcarenites and conglomerates); Pi: Lower Pliocene (marls); O: Oligocene conglomerates; C9: Marly calcareous of Maastrichtian; C8: Marly calcareous of Campanian, $\boldsymbol{C 7 b}, \boldsymbol{C 7 a}$ : Marls with levels of limestone (b: Santonian; $\boldsymbol{a}$ : Coniacian); $\boldsymbol{C 6}$ : Limestones with silex of Turonian; C5-4: Marls of Cenomanian; C3: Vraconian marls; C2: Albian clays.
(Fig. 8), parallel to the straightened Cretaceous beds of the Atlas border fold (anticline of the kasba). This structure is in fact a secondary fold to the head of the anticline of Ait Lamine, and assigns to this folding an overlap tendency to the south. Cretaceous layers slope in the Souss plain under the Tertiary cover, and come out again only after hundreds meters of dislevelment lower than Ait Lamine. In the same way, the Moghrebian marine terrace of the kasba is parceled out and presents a vertical shift of $200 \mathrm{~m}$.

The Tikiouine Villafranchian anticline (about $8 \mathrm{~km}$ to the east of Agadir), underwent a little reactivation during the Quaternary. A little more to the east, the hot springs of Gonna indicate probably there also, a deep recent repeat of a some longitudinal accidents of Souss.

Although the results from the seismothem dating are not yet known, it seems that the distur-

bances noticed around Agadir are recorded in the endokarstic system, where the impact of the Atlasic effect in terms of horizontal and vertical motions are underlined. A real natural laboratory is at our disposal in this system, which has to be preserved as national patrimony. In fact, the Agadir endokarstic system is just starting to reveal its rich history about paleoseismic events in the whole western part of the High-Atlas. It is planned to extend this approach to all Moroccan karst systems, especially in the Mediterranean domains. 


\section{Bulgaria}

More than 70 local paleoseismic dislocations have been recorded in Bulgaria up to now that are dated to have taken place before 8000 B.P. (Fig. 9). They occurred entirely in limestone and marble of different age. For the present, the predominating part of the investigations refers to surface karst. The underground investigations and the speleothem dating are lagging behind (Angelova 1995, 1996, 1999, 2000, 2001, 2003; Kostov 2000; Shanov et al. 2001; Angelova et al. 2002). In most cases the paleoseismic dislocations result from one-act earthquake event but there are also repeatedly activated movements. The natural relationships have been disturbed in the surface and underground karst relief and a specific type of relief has been created. It is represented in its essence, origin and relief by extremely interesting natural phenomena.

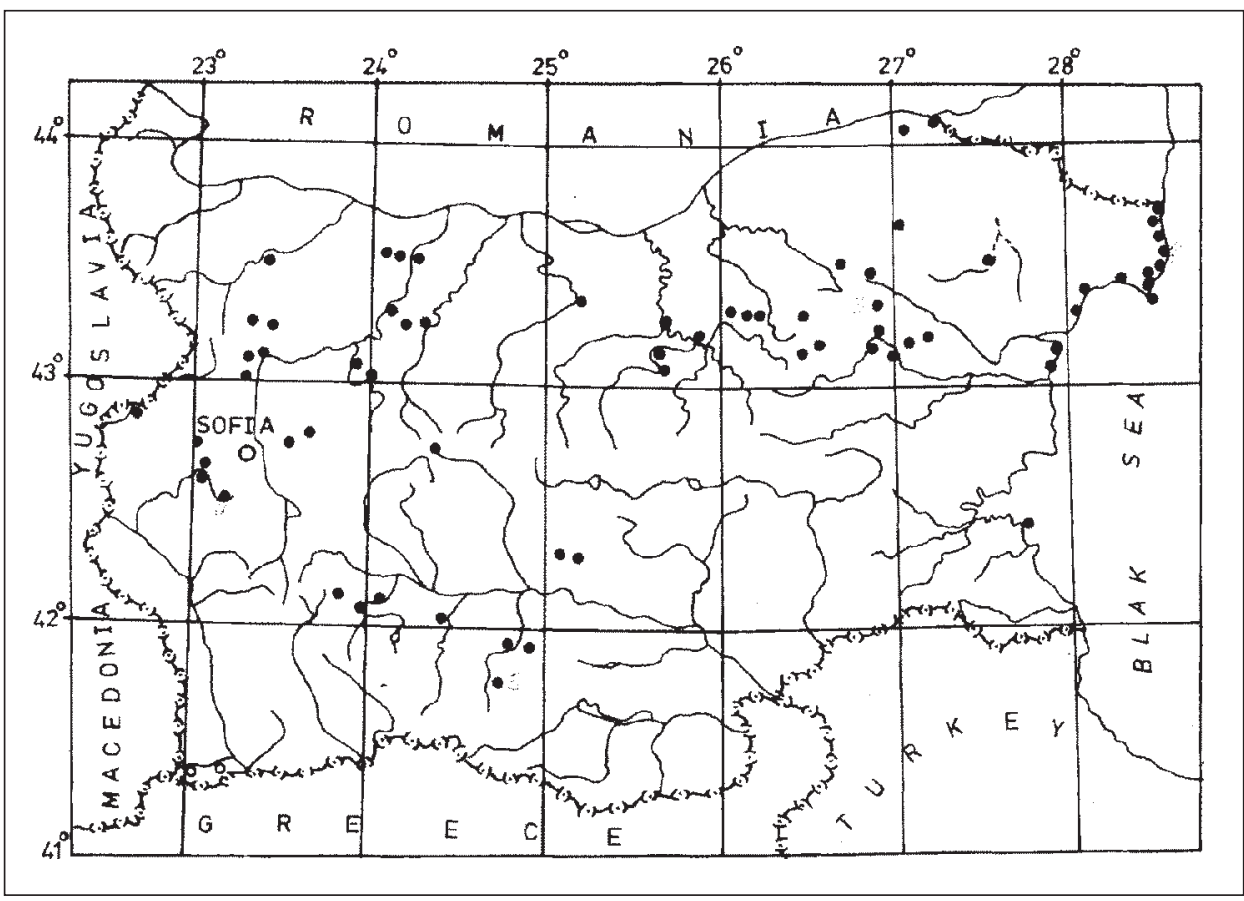

Fig. 9: Map of the situation of the paleoseismic dislocations in karst terrains in Bulgaria.

The "Madara" paleoseismic phenomenon is situated in the northern periphery of the Madara Plateau (Fig. 10). The "Madara Horseman" bas-relief dating back to the Early Middle Ages was cut into the rocks (Photo 1). This unique monument is included in the World Cultural Heritage List and is under the auspices of UNESCO. There are remnants from the times of primitive man (the Stone-Copper age - 4000 B.C.) in the rock pediment. About 200 relatively well preserved monk-cells date back to the Late Middle Ages. The contemporary geodynamic position of the Madara Plateau, which is situated at the contact zone between two lithospheric plates, is characterized by diverse local brittle and plastic tectonic deformations and related processes and phenomena. The morphostructural upgrading is not a completed process. Moreover, the circumstances 


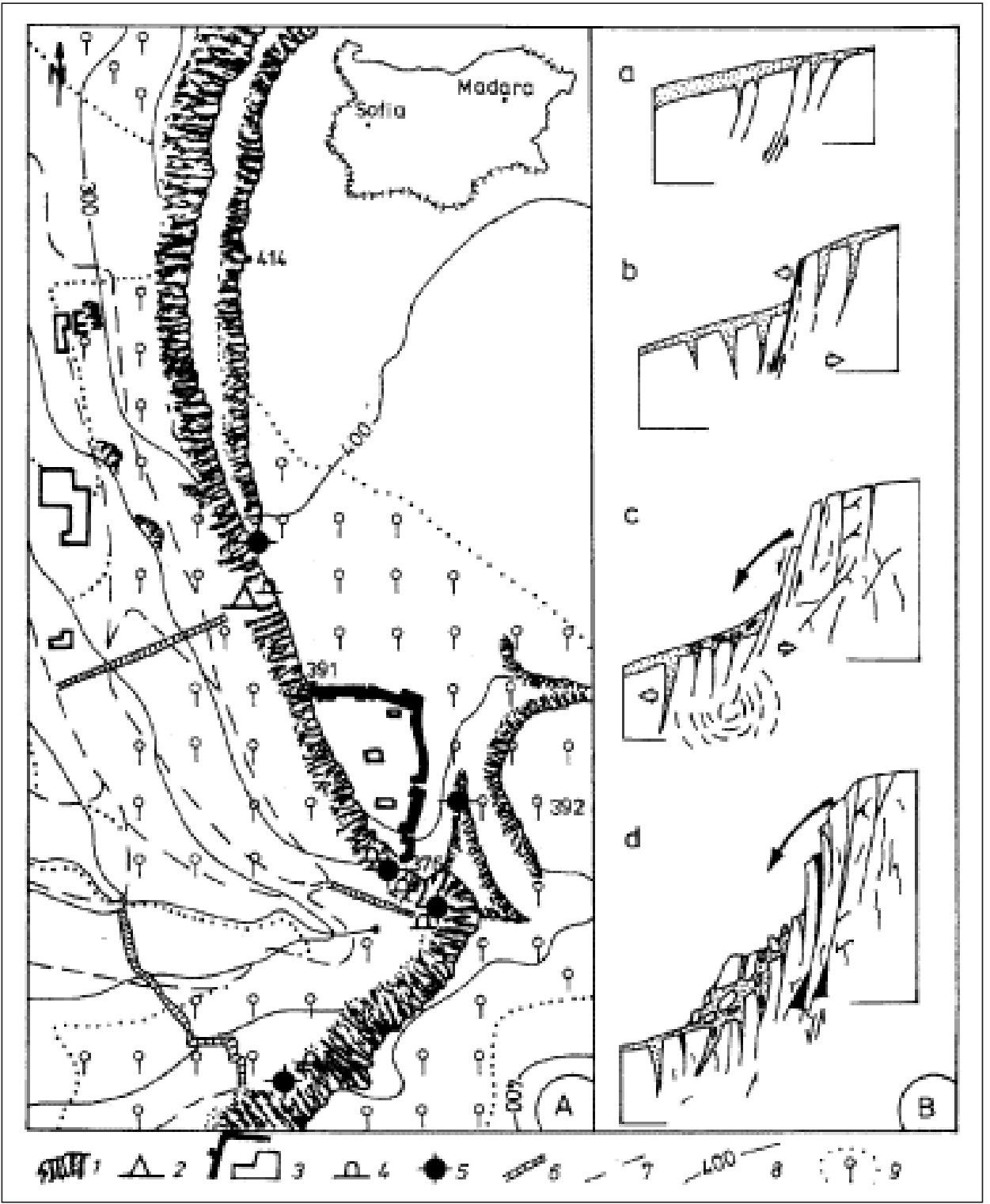

Fig. 10: A. Situation map of the region of the Madara Horseman monument: 1 - rock slopes and single gravitation blocks; 2 - the Madara Horseman monument; 3 - fortress walls and architectural complexes and monuments from Roman, Old Bulgarian and Medieval culture; 4 - gravitation caves and precipice caves; 5 - paleoseismic dislocation; 6-7 - tourist routes: 6 - stairs, 7 - alleys; 8 - horizontals; 9 - park. B. A model of the Madara Plateau formation (according to the sample model of Montenat et al. 1991): a - prior to the Quaternary; $b$ - beginning of the Quaternary; $c$-Middle Pleistocene; $d$ - present stage. 


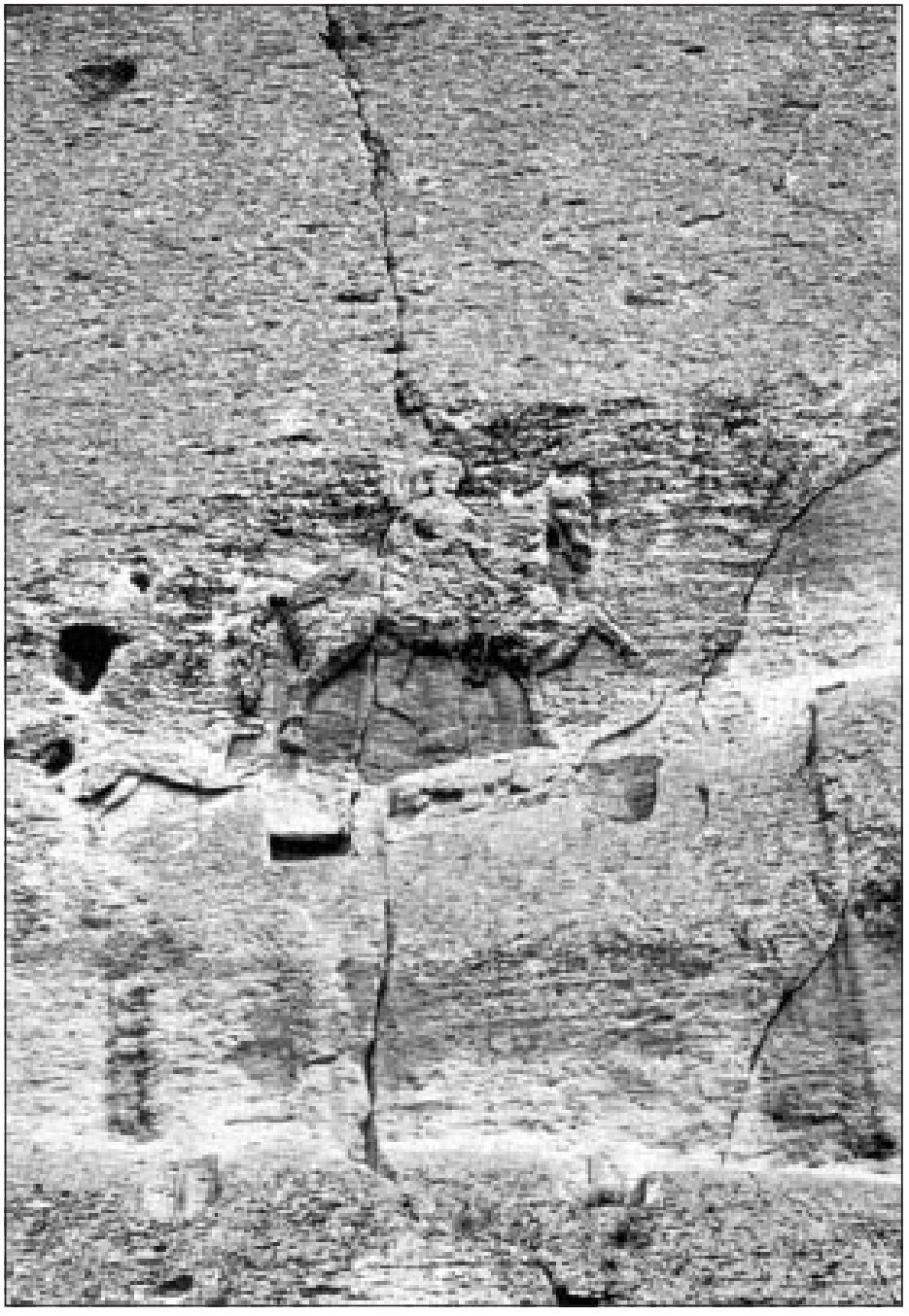

Photo 1: The famous bas-relief image (the oldest rock bas-relief) of the Madara Horseman was cut into the earthquake-torn rock plate during the $9^{\text {th }}$ century. The historic monument is under the protection of UNESCO and is included in the World Cultural Heritage list. Remains from primitive men, Romans, Old Bulgarians and the First Bulgarian Kingdom are found in this place. It is also a natural geological-geomorphological phenomenon.

and by landslide-rockfall processes with characteristic step in the slopes in the direction towards the plateau interior due to the action of erosion and the subsequent tectonic slow and impulse movements. have been complicated by the increased induced potential seismic hazard, connected with the anthropogenic impact on the closely situated salt body. For this reason it was necessary to study the whole natural and anthropogenically disturbed environment. As a result of this investigation, significant relief disturbances were established, which had been provoked by catastrophic earthquakes during the present, the historic and pre-historic stages. These events have built a very specific relief from the disturbed natural one.

The initial surface was broken apart under the influence of the initial tectonic impulse and the formation of the foot of the plateau started. This surface was separated in the northern border of the plateau by the adolescent valley of the Madara River 


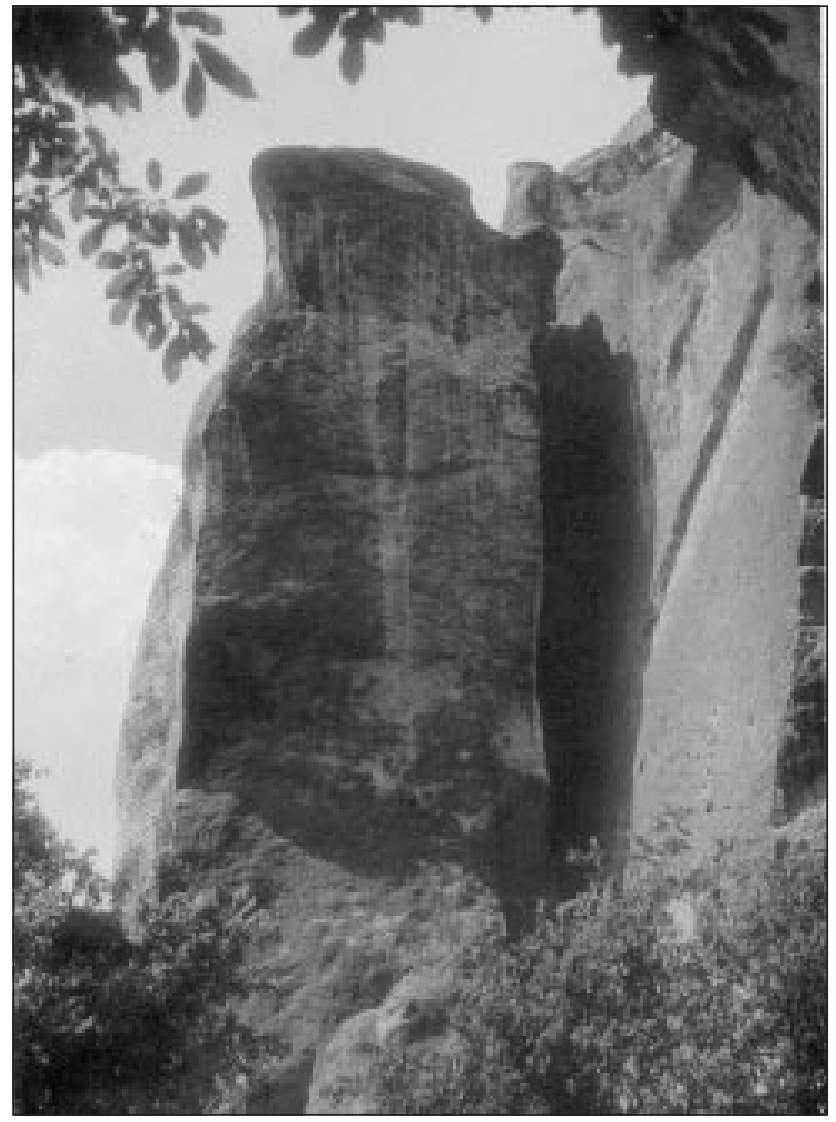

Photo 2: The Madara paleoseismic dislocation.

During the Middle Pleistocene the regions in the vicinity of the monument and the area to the north and northeast of the Kyulevcha and Madara villages were subjected to impulse movements correlating in time with the formation of the third and fourth over-flood terraces, causing the formation of the two landslide terraces. The Madara paleoseismic dislocations were formed as a result of the earthquake events, their known length being 1.0$1.5 \mathrm{~km}$ in northeast-southeast direction. Both dislocations were of the seismic-gravitation type. Open cracks originated in the core massif and the shifted torn and slid masses to the north and north-west reached a height of up to $1 \mathrm{~km}$ from the initial $100-140 \mathrm{~m}$ in the part of the slope, where the seismogenic fault was situated.

The width of the earthquake crack, marking the already torn scale from the time of its formation till now, reached $0.8 \mathrm{~m}$ in its upper part and more than $1.5 \mathrm{~m}$ in the lower part, where the Malka cave is located. The crack exhibits a tendency to increase under the influence of gravitation. According to the classifications this phenomenon could take place when $\mathrm{I}_{0}=10-11, \mathrm{M} \geq 7-8$ and the depth of the focus was from 2 to $10 \mathrm{~km}$ (Photo 2 and Photo 3).

The Holocene also started with numerous differentiated vertical and horizontal movements, which led to different rising and rolling of the structural edges, banks, deformation of the built relief forms and hence to changes in the slope inclination and transition to a new dynamic state of the slope process, accompanied by rockfalls, unsticking, adjustment of the river-valley network along the fault structures, block disintegration and enhancement of the weathering processes along the strongly developed fissure network.

The region of the Madara Horseman monument was very mobile in neotectonic aspect. It fell within the second (Madara) block with maximal values of vertical rising of $250-300 \mathrm{~m} / \mathrm{km}^{2}$, i.e. the vertical component was the predominating one. The most actively displayed horizontal movements in this block were in a northwest direction. The block was characterized by small trans- 


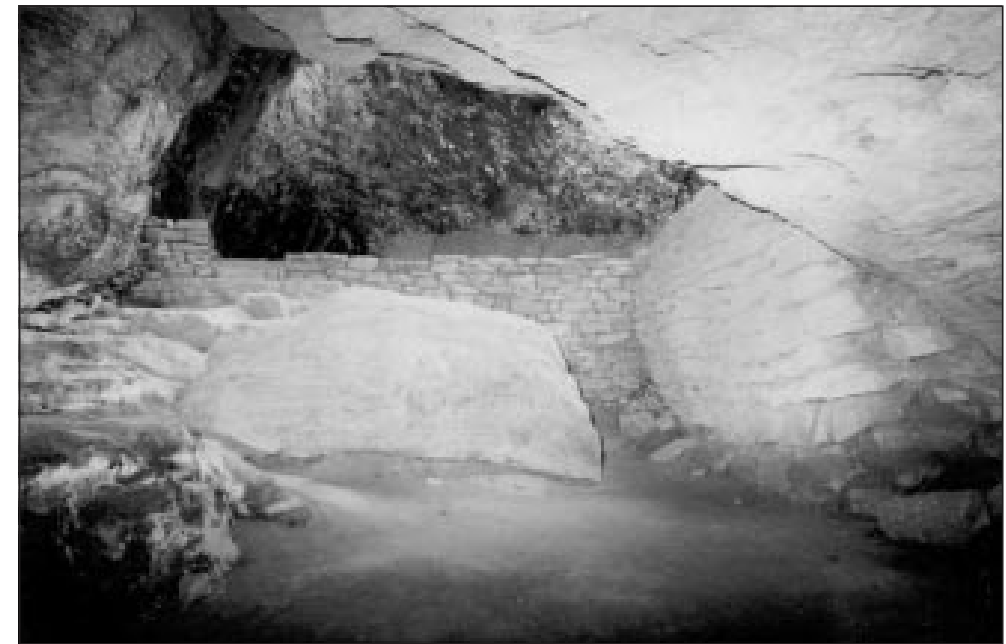

Photo 3: The "Madara" paleoseismic dislocation and the Malkata gravitation cave, formed by a paleoearthquake and inhabited by primitive men (the Stone-Copper Age, 4000 B.C.). verse faults of significant morphogenic importance. Blocks of different sizes were formed at the foot of the slope. The rockfalllandslide formations were incised by ravines of Holocene and contemporary age (Fig. 10B).

The contemporary stage had been characterized by uncompensated verti-

cal and horizontal movements. The neotectonic situation became more complicated as a result of these movements and several new fault structures were formed. They were sub-parallel, transverse and more seldom - oblique, to the main direction of the layer surfaces. Four main groups of cracks could be distinguished according to their direction: $360^{\circ}$ (vertical), $150^{\circ} / 80^{\circ}$ to the southwest, $65^{\circ}$ (vertical) and $130^{\circ}$ (vertical). There were also slanting cracks coinciding with the slope of the layer surfaces (inclination of $10-15^{\circ}$ ). The latter confirms the seismotectonic origin of the cracks, connected with weakening of the bonds along the surface and opening of the tectonic wedges in the base of the slope (Fig. 10B).

The crack origin was accompanied by the formation of seismic-dome structures and a complex system of cracks and collapses. The cracks from the meridional group were very intensive in exodynamic respect. Weathering processes took place along the crack system under the influence of atmospheric agents. The regional contemporary vertical movements amount to $2.0 \mathrm{~mm} / \mathrm{year}$ for the high part of the plateau. Local blocks with dynamics of 3.0 to $5.0 \mathrm{~mm} / \mathrm{year}$ are observed and for the pediment the data are: $+1.7 \mathrm{~mm} / \mathrm{year}$ for the Kyulevcha village, $+1.8 \mathrm{~mm} / \mathrm{year}$ for the Madara village, $+2.1 \mathrm{~mm} / \mathrm{year}$ for the Kalugeritsa quarter and $+2.0 \mathrm{~mm} / \mathrm{year}$ for the Kaspichan town. The Kyulevcha block is the most active one at present, which is expressed in enhanced rockfall-landslide processes and phenomena, enhanced ravine formation, destruction of engineering facilities. The horizontal movements have a relatively constant value of $1.0 \mathrm{~mm} / \mathrm{year}$. Contemporary seismic dislocations with destructive effect have been fixed in the region - the collapse above the Nimfite cave in 1928 and the rockfall above the Kyulevcha village as a result of the Vrancea earthquake in 1977 (Angelova 1995, 2001). The latter widened the crack in the Madara Horseman monument. The region falls within the Shoumen seismotectonic zone and is characterized by higher induced potential seismic hazard related to the anthropogenic influence on the Provadia salt body. 
The present investigation has proved that the disintegration of the Earth's crust at the place is higher than that presumed so far. The instrumentally recorded earthquakes do not exceed $\mathrm{M}=6.0-7.0$, but the established paleoseismic dislocations with sensitive relief deformations show that individual seismicity is displayed in the region with hypocentre depths in the range of $2-10 \mathrm{~km}$.

The rock bas-relief of the Madara Horseman and the inscriptions around it are split by several bigger and smaller cracks. They pass mainly in front of the horseman and behind it. They are extensively documented in all investigations carried out in the region and for this reason their morphology will not be considered here. They have been described in all research works and in many of them they are referred to as cracks of erosion genesis. The problem whether they could be of tectonic genesis and whether slow tectonic movements are realised along them, is a debatable problem of crucial importance in Bulgarian reference literature. Regardless of all these "discussions", the presence of fresh cracks, along which no erosion processes have been developed, the existence of the Smelite Ochichki shaft immediately near Madara Horseman with a completely vertical $83 \mathrm{~m}$ high slope and a horizontal gallery between the blocks behind and in the foot of the monument (the width of the open part reaching $3.2 \mathrm{~m}$ ), the active faults and the opened cracks observed in the vicinity, provide incontestable evidence about their origin.

During the subsequent mapping to the east of the Kaspichan railway stations and along the valleys of the Provadiiska and Kamchia Rivers, as well as in the interior of the Provadia Plateau, other paleoseismic relief disturbances of the gravitation type were established too. They caused the destruction of cultural monuments, disturbances in the caves, deformations in the river terraces, etc. The monitoring carried out in the region of the salt body has proved that there are vertical deformations too along the periphery of the salt stock. Monthly about 20-30 earthquakes with $M=1-3$ are recorded in the region. Inert material quarries are operated around the salt body

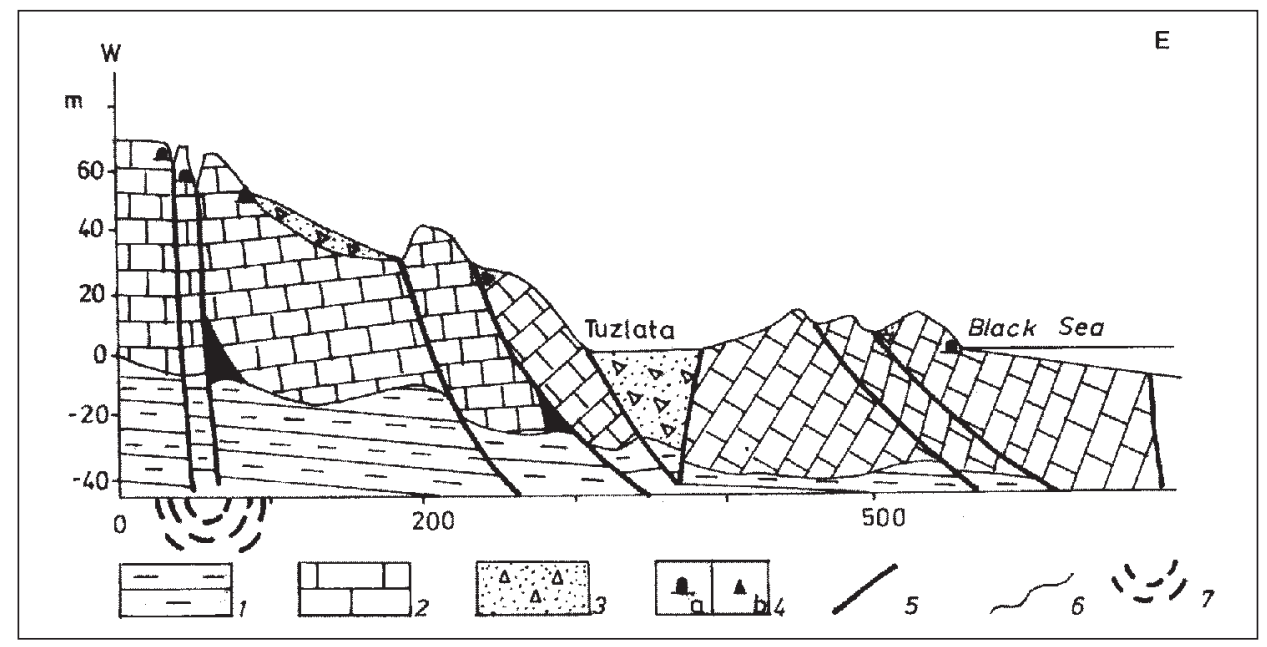

Fig. 11: Geological-geomorphological profile in the region of the "Taukliman" paleoseismic dislocation: 1 - Oligocene marls; 2 - Sarmatian limestones; 3 - colluvial materials; 4 - caves: a) natural, b) gravitational; 5 - fault; 6 - landslide surface; 7 - place of localisation. 


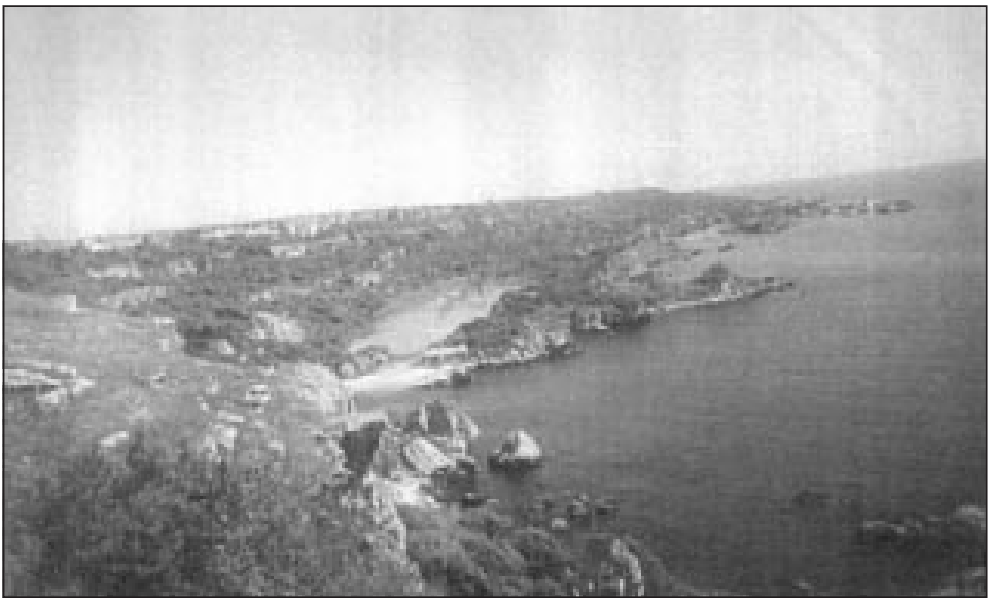

Photo 4: Panorama of the "Taukliman" paleoseismic phenomenon. and according to the opinion of researchers, this makes it difficult to distinguish between the natural seismicity and the imposed technogenic one. There are historical data for the region that there were e a r thquake events causing considerable destruction in the settlements before the exploitation of the salt body began. The investigations showed that the earthquake hypocentres were not observed in the salt stock itself, but around it

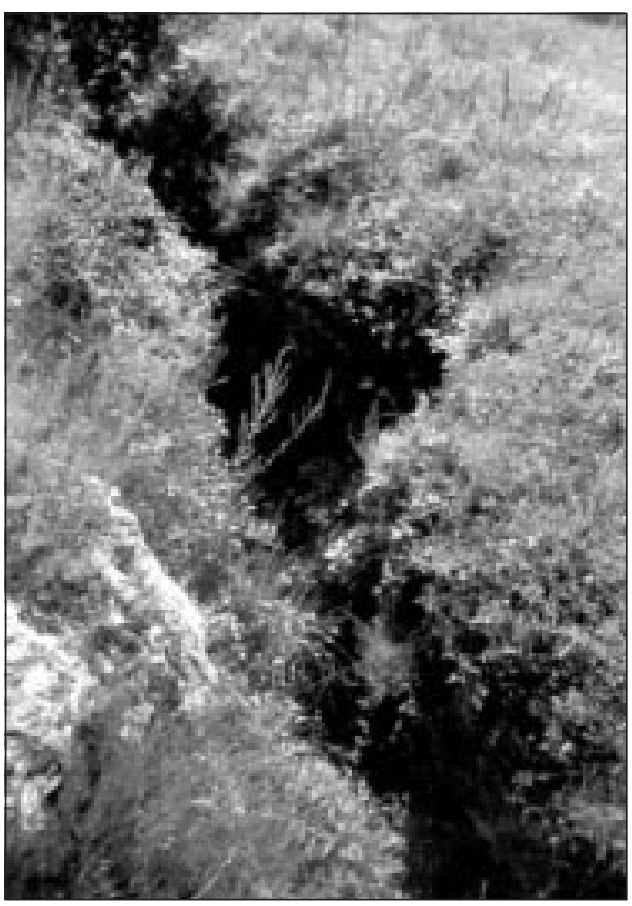

Photo 4a: Detail from the "Taukliman" paleoseismic dislocation. and it had been assumed to result from the shifting of halogen masses in the cracks as well as from the motion of groundwater during the diaperism, seismic genesis and tectonic deformations. The "Taukliman" paleoseismic phenomenon has the status of a protected locality according to the Bulgarian environmental legislation (Kozhuharov \& Angelova 2000) (Fig. 11, Photo 4). The "Taukliman" paleoseismic dislocation includes not only the tectonic disturbances of the relief in the coastal zone but also those situated to the east of the Nakevo village in the Kayryaka and Kayraktarla localities. The landslides of seismic-gravitation type have been studied by many authors. The formation of this landslide complex began during the earthquake event at the Pliocene-Quaternary boundary along the Tyulenovo fault. It had a NNE-SSW direction that coincided with the seacoast. Local deformations with amplitude between 10 and $40 \mathrm{~m}$ were established along this fault (Photo 4a).

The karstified Sarmatian limestones around this fault structure were cracked par- 
allel to it. The paleoearthquake at the Pliocene-Quaternary boundary marked the epicentre of this event, situated in the cross-point of the fault structures directed to the N-NE and SE-NW at a distance of $120 \mathrm{~m}$ above the sea level. The NE fault formed also the tectonic landslide near the Yailata. The paleoearthquake had a much greater range and the position of the landslide bank was about 150-200 $\mathrm{m}$ inside the sea. The analysis of the landslide bodies shows that they were between 6-7 for the Taukliman and 3-4 for the Yailata region. This provides evidence for the fact that the landslide bodies were not torn away simultaneously but during different stages.

The genesis and development of the seismic-gravitation steps proves that the seismic-tectonic structure was reactivated 3 or 4 times and that the events were related to the global changes in the sea level accompanied by tsunami. The other steps resulted from the slow landslide pulsating activation. During the historic stage the Thracian settlement of Tirizis, situated at Taukliman (2500-3000 B.C.) and the settlement from the $3^{\text {rd }}$ century B.C., were destroyed and abandoned as a result of the occurring big earthquakes. The region was repeatedly reactivated during the contemporary stage. The earthquake in 1901 (epicentre Shabla, $\mathrm{M}=7.2$ and $\mathrm{I}_{0}=\mathrm{IX}-\mathrm{X}$ ) reactivated the landslide process. Vertical and horizontal cracks were formed, houses, minarets, mosques and historic monuments were destroyed. The village of Nakevo was entirely ruined, there were human deaths too. Deformations in the slopes of the Kamen Bryag - Nakevo anticline and the Bulgarene and Kavarna anticlines took place. Forms inverse to the tectonic relief were created.

The "Srebarna" karst wetland including the homonymous swamp-lake was formed at the Holocene-Pleistocene boundary (10500 \pm 250 B.P.) as a result of a catastrophic earthquake. The length of the contemporary hypereutrophic swamp is about $2.5 \mathrm{~km}$, the width - about $1.8 \mathrm{~km}$, the area $-2 \mathrm{~km}^{2}$ and the depth $-0.7-3 \mathrm{~m}$ (Photo 5).

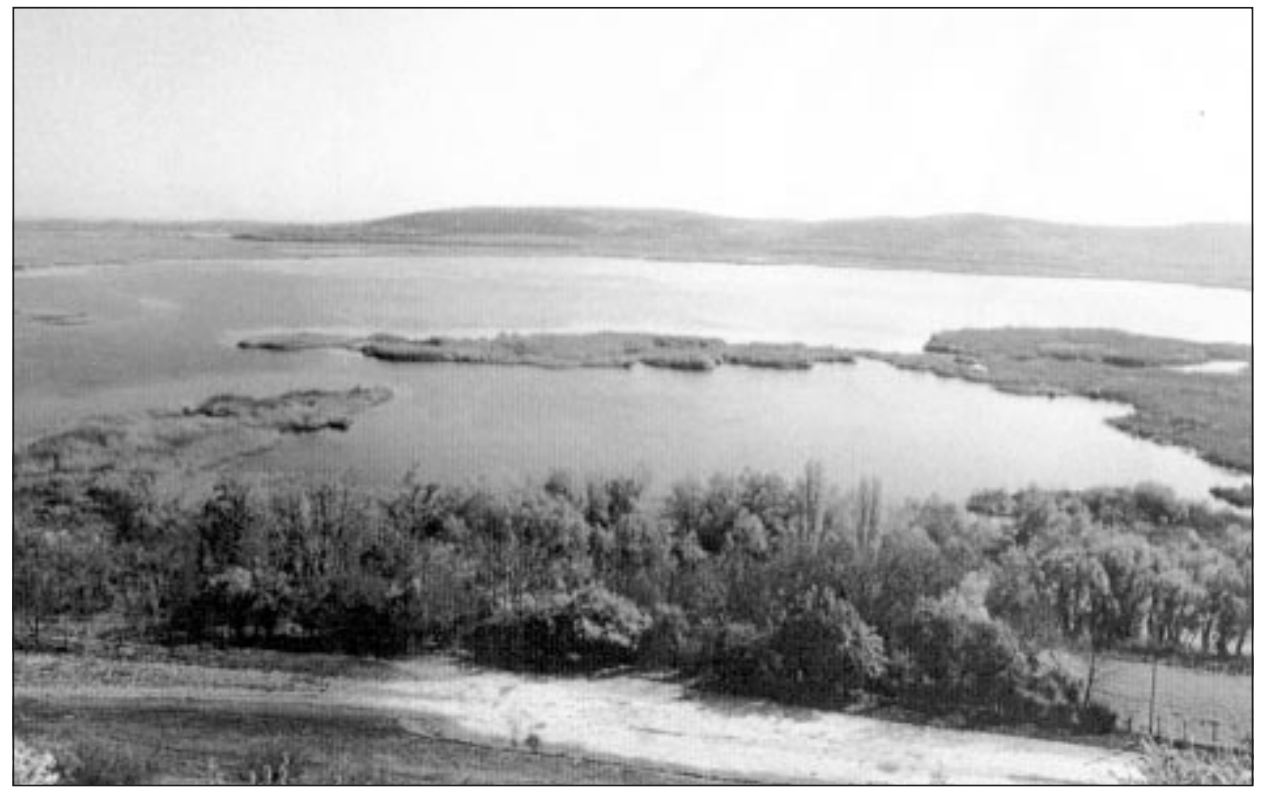

Photo 5: View of the "Srebarna" wetland. 
About half of the wetland territory has been destroyed during the drying carried out in 1949 . The ecobiotas are characterized by numerous rare and extinct species - mainly 179 bird species, 50 of them being included in the Red Book of Bulgaria (1985). Ninety of the species are of European importance for nature protection. The "Srebarna" wetland was proclaimed to be a reserve in 1948 and a biosphere reserve - in 1977. It was included in the World Cultural and Natural Heritage list of UNESCO in 1983. It has been acknowledged to be a wetland of international importance (Ramsar Convention, 1976). The territorial range of the protected territory is 760 ha. The site was in ecological collapse in 1990-1992 and urgent interdisciplinary investigations had to be carried out and a number of measures to be taken for overcoming the crisis and maintaining a constant water level.

There is a paleoseismic dislocation in the area, named after the Srebarna village. A residual relief deformation had been caused in its vicinity by a one-act event at the Holocene-Pleistocene boundary. It had caused the bifurcation of the Srebarna and Karlezhka River mouths and the formation of the swamp (Fig. 12).

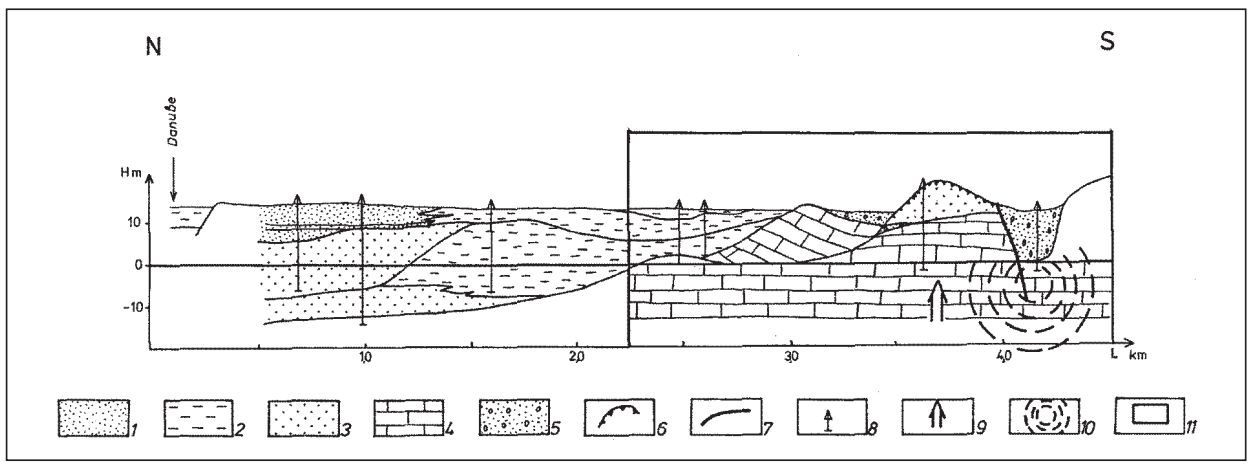

Fig. 12: Geological-geomorphological profile of the "Srebarna" paleoseismic dislocation: 1 - Tarlica Pebble-sand-clayey Formation (Upper Holocene); 2 - Todoranka Clayey Formation (Lower-Upper Holocene); 3 - undivided Lower Holocene alluvial deposits; 4 - Russe Formation (Baremian-Aptian); 5 - accumulative pockets; 6 - relief deformation; 7 - paleoseismic dislocation area; 8 - borehole locations; 9 - block displacement orientation; 10 - event localisation; 11 - earthquake influence area.

An arch-bent structure (river terrace) was uplifted $10 \mathrm{~m}$ above the contemporary swamp level. Its pebble-sand alluvial deposits were formed in such a manner that they formed a 10-12 $\mathrm{m}$ deep pocket near the normal fault. This fact and the presence of gravitational deformation in front of the pocket have to be considered as evidence for a sudden displacement on the fault plane with a short-term opening accompanied by a simultaneous subsidence or abatement of the superficial alluvium deposits. All the above mentioned facts prove the seismogenic character of the considerd rupture. The known maximum dimensions of the paleoseismic dislocation are: length $-2750 \mathrm{~m}$, width - from 750 to $1000 \mathrm{~m}$, vertical displacement - $20 \mathrm{~m}$. The age of the paleoseismic dislocation was determined on the basis of analogies with rock units (Angelova 1995) - 10500 \pm 250 years. 
The "Srebarna" paleoseismic dislocation is localised within the confines of a big longitudinal first-rank tectonic zone, which has an ESE strike that includes also the Danube River delta (Nikonov \& Nikonova 1990). It reflects the complex configuration of longitudinal (regional) and meridional (local) structures. The formed tectonic junction marks the epicentral area of the earthquake.

The geological structure of the shifted block, its geomorphological features, the one-act phenomenon as well as the gravitational deformation, were controlled by the local tectonic activity with a possible intensity of VIII-IX degree according to the classification of Solonenko. The problem concerning the depth of the focus is still unsolved. This depth can be estimated as 30-60 $\mathrm{km}$ on the basis of the rupture length, vertical block displacement and presumable intensity.

According to instrumental data, the region was reactivated in 1864, 1892 and 1893. The data published by Nikonov \& Nikonova (1990) refer to an earthquake that took place in the Danube River delta on October 14, 1892 (intensity of VII-VIII degree, energy class - 9 degree, focus depth $-60 \pm 10 \mathrm{~km}$.

According to geodetic data about the recent vertical displacements surveyed on a regional scale, the zone belongs to a stable area with displacement velocity of $0 \mathrm{~mm} / \mathrm{year}$ (Totomanov et al. 1970). The recent vertical local displacements of the smaller blocks show a differentiated character with various signs: Silistra $+0.10 \mathrm{~mm} /$ year, Aydemir $+0.80 \mathrm{~mm} /$ year, Popina $+0.40 \mathrm{~mm} /$ year, etc. Recent swamping in the investigated region indicates in most cases a local tectonic subsidence.

As a result of the investigations it has been established that the initial relief in the region of "Srebarna" had been strongly deformed by a catastrophic earthquake (Angelova 1995, 1999, 2000, 2001). The contemporary stage in the development of "Srebarna" had inherited the general character of the morphogenetic processes: continuation of the exogenic and endodynamic relief processing, strong anthropogenic impact, enhanced deep and lateral erosion, uncompensated tectonic movements, soil and wind erosion, gravitation processes, enhanced accumulative processes, engineering impacts. As a result, the natural feeding with karst water from griffons and the water fluctuation is high and there are collapse changes in the karstification levels, etc.

\section{CONCLUSION}

The investigated territories in Bulgaria and Morocco are situated in different nodal geodynamic regions of the Mediterranean, which are of world or state importance. The paleoseismic events that occurred in karst terrains provoked or could provoke serious ecological problems. Regardless of this, they have created a specific type of relief with characteristic extremely beautiful landscapes and nature. The investigations of these phenomena in karst terrains should be continued purposefully and should be subjected to continuous monitoring because the consequences for the natural and anthropogenized environment could be reflected in the whole social life. 


\section{REFERENCES}

Ambroggi, R. \& Neltner, L., 1952: Livret guide de l'Excursion C33's Haut-Atlas et Anti-Atlas Occidentaux. XIX Congrès Géologique International, Alger, 1952. Service Maroc, 13, 82 p.

American Iron and Steel Institute, 1962. The Agadir, Morocco Earthquake, February 29, 1960. Monography. Committee of Structural Steel Producers, 112 p.

Amrhar, M., 1989: Apport des méthodes d'analyse de la tectonique cassante à l'histoire alpine du Haut-Atlas occidental: exemple du bloc ancien du Haut-Atlas d'Agadir. Thèse $3^{3 \text { ème }}$ cycle, Univ. Cadi Ayyad. Marrakech, 174 p.

Angelova, D., 1995: Neotectonics and Geodynamics of the Madara Plateau. Problems of Geography, 2, 75-84 (in Bulgarian).

Angelova, D., 1996: Neotectonic and Geomorphological Characteristics of the Western Part of the Aydemir Lowland, Silistra District. Geologica Balcanica, 26, 3, 53-57 (in Bulgarian).

Angelova, D., 2000: Tectonic Prerequisites for the Karst development in the Stara Planina Iskar Gorge. Proc. of the National Scientific Conference on Problems of Karst and Speleology, Sofia, March 1999, 43-50 (in Bulgarian).

Angelova, D., 2001: Paleoseismic Studies in the Moezian Platform (Bulgaria). Risk Effect of the Pre-historic Paleoseismic Dislocations. Tectonique active et géomorphologie. Revue d'Analyse Spatiale, No spécial, France, 2001, 9-15.

Angelova, D., 2002: Paleoseismic Events in Karst Terrains along the Northern Bulgarian Black Sea Coast. Acta Geologica Sinica, J. of the geol. Soc. of China, vol. 75 (in press).

Angelova, D., 2002: The Bosnek Karst Region (Bulgaria) - a Phenomenon and Geological Problems. Karst Protection, Despotovac, Yugoslavia (in press).

Angelova, D., 2002: Paleoseismic Dislocations in Karst Terrains in Northeast Bulgaria. Environment and Cultural Heritage in Karst, Sofia (in press).

Angelova, D., 2002: Geomorphological Maps of Bulgaria in Scale 1:100000. Map Sheets Kozloduy, Byala Slatina, Knezha-Gigen, Pleven-Nikopol, Alexandria-Svishtov, Popovo, Razgrad, Novi Pazar, Dobrich, Shabla-Balchik, Provadia, Shoumen, Silistra and Explanatory Note to Them.

Angelova, D., Belfoul, M. A., Filahi, M., Bouzid, S. \& Faïk, F., 2002: Paleoseismic Deformations in Karst Terrains in Bulgaria and Morocco. Proc. Jubilee Int. Cong. in Memoriam to Prof. Dr. D. Yaranov, Varna (in press).

Belfoul, M.A., 1997: Expédition internationale de spéléologie: Spécial Wintimdouine, Juillet 1997. Rapport inédit présenté lors de la séance de clôture au comité d'organisation. Agadir, Maroc.

Bouzid, S., Belfoul, M.A., Faïk, F. \& Oudra, M., 2001: Endokarstes et spéléothèmes: marqueurs d'activités naturelles sismotectoniques ancienne et récente. Perspective d'application à des exemples régionaux. Workshop international sur la sismicité et la gestion du risque sismique dans la région Euro-méditerranéenne, Agadir, Maroc, 18 et 19 juin 2001. Résumé, 27.

Belfoul, M.A., Qurtobi, M. \& Faïk, F., 2000: Impact de la structuration atlasique sur l'architecture interne de la grotte de Wintimdouine (Haut-Atlas occidental marocain). Colloque international «Riviera 2000: Tectonique active et Géomorphologie», Villefranche sur mer, Octobre 2000, France. 
Choubert, G. \& Faure-Muret A., 1962: Le séisme d'Agadir, ses effets et son interpretation géologique. Notes et Mémoires du Service Géologique du Maroc, 154, 53-68.

Debrach, J., 1962: Rapport préliminaire du service de physique du globe et de météorologie sur le tremblement de terre du 29 Fevrier, 1960 à Agadir. Notes et Mémoires du Service Géologique du Maroc, 154, 31-41.

Duffaud, F., 1962: Le cadre géologique de la région d'Agadir. Notes et Mémoires du Service Géologique du Maroc. 154, 5-6.

Erimesco, P., 1962: Le tremblement de terre dans la Baie d'Agadir. Notes et Mémoires du Service Géologique du Maroc, 154, 43-52.

Kostov, K., 2000: Data about Quaternary Tectonic Activity in Labirinta Cave in the Stara Planina Iskar Gorge, NW Bulgaria. Theoretical and Applied Karstology, Romania, vol. 11-12/ 1998-1999, 17-21.

Kozuharov, E. \& Angelova, D., 2000: The Coast of Bulgaria - an Environmental review. Ministry of Environment and Water, $36 \mathrm{p}$.

Marcais, J. \& Choubert, G., 1956: Les grands traits de la géologie du Maroc. Lexique stratigraphique du Maroc: introduction géologique. Direction des mines et Géologie. Rabat, Maroc.

Montenat, C., Barrier, P. \& Ott d'Estevon, Ph., 1991: Some Aspects of the Recent Tectonics in the Strait of Messina, Italy. Tectonophysics, 194, 203-215.

Nikonov, A. \& Nikonova, K., 1990: On the Seismic Hazard in the Danube River Delta according to Data about Historic earthquakes. Problems of Engineering Seismology, 31, Moscow, Nauka, 126-134 (in Russian).

Shanov, S., Kourtev, K., Nikolov, G., Boykova, A. \& Benderev, A., 2001: Paleoseismological Traces in the Lepenitsa Cave, Velingrad District, South Bulgaria. Revue d'Analyse Spatiale, No special, France, 2001, 151-154.

Totomanov, I., Vrablyanski, B. \& Mladenovski, M., 1970: Investigation and Mapping of the Contemporary Earth's Crust Vertical Movements in Bulgaria. Problems of Geography, 3, 68-74 (in Bulgarian). 